\title{
Chemical Composition and Nutritive Value of Agro-Industrial By-Products in Ruminant Nutrition
}

\author{
Eyob Haile1, Francis K. Njonge ${ }^{2}$, Goitom Asgedom1, Mathew Gicheha ${ }^{2 *}$ \\ ${ }^{1}$ Department of Animal Sciences, Hamelmalo Agricultural College, Keren, Eritrea \\ ${ }^{2}$ Department of Animal Sciences, Jomo Kenyatta University of Agriculture and Technology, Nairobi, Kenya \\ Email:^gicheham@jkuat.ac.ke, ^gichehag@yahoo.com
}

How to cite this paper: Haile, E., Njonge, F.K., Asgedom, G. and Gicheha, M. (2017) Chemical Composition and Nutritive Value of Agro-Industrial By-Products in Ruminant Nutrition. Open Journal of Animal Sciences, 7, 8-18.

http://dx.doi.org/10.4236/ojas.2017.71002

Received: November 8, 2016

Accepted: December 24, 2016

Published: December 27, 2016

Copyright $\odot 2017$ by authors and Scientific Research Publishing Inc. This work is licensed under the Creative Commons Attribution International License (CC BY 4.0).

http://creativecommons.org/licenses/by/4.0/

c) (i) Open Access

\begin{abstract}
This study was carried out to determine the chemical composition and in situ degradability of agro-industrial by-products found in Eritrea. Three categories of byproducts were evaluated and were the milling industry (wheat bran; WB, short; WS, and middling; WM), brewery (brewers' dry grain; BDG, hops; BDH, and yeast; BDY) and sesame cakes (sesame cake machine extracted; SCM and manually extracted; SCT). The dry matter (DM) varied between $88.46 \%$ in BDY to $92.39 \%$ in SCT. The lowest $(\mathrm{P}<0.05)$ crude protein $(\mathrm{CP})$ content was recorded in $\mathrm{WM}$ at $10.11 \%$ while the highest was from the BDY at $48.20 \%$. The metabolisable energy (ME) value of the agro-industrial by-products ranged from 8.72 to $11.18 \mathrm{MJ}$ per $\mathrm{kg} \mathrm{DM}$ with the $\mathrm{BDH}$ recording the lowest value $(\mathrm{P}<0.05)$. The sesame cakes $(\mathrm{SCM}$ and SCT) recorded higher values of 11.17 and $11.18 \mathrm{MJ}$ per kg DM respectively. The SCT recorded the highest ash content at $10.93 \%$ followed by BDY at $10.16 \%$ with the least being obtained from WM at $2.48 \%$. The ether extract and acid detergent lignin contents were generally low in all cases for all the by-products. Generally, the results indicated that there was no clear pattern in terms of nutrients content amongst the by-products. The in situ DM, organic matter (OM) and CP degradability differed amongst and within the sesame cakes, milling and brewery by-products. The wide variation in chemical composition, DM, OM, CP degradability, and ME obtained from this study offer farmers huge flexibility in formulating rations according to the productive performance of target animals.
\end{abstract}

\section{Keywords}

Chemical Composition, Nutritional Value, Agro-Industrial By-Products

\section{Introduction}

There is potential for increased livestock production in Eritrea through use of agro- 
industrial by-products as a supplement in ruminant diets. The bulk of livestock feed (estimated to be about 90\%) comes from grazing on pastures and stubble. According to [1], grazed pastures in Eritrea are declining partly as a result of overgrazing aimed at producing more protein to satisfy the increasing demand resulting from an increase in human population. This coupled with climate change and increased climatic variability has resulted in reduction in nutrients available for grazing stock thus compromising productivity. Besides the increase in the protein demand, competition for cereal grains between animal and human has been on the rise leaving very little for use in animal feeding. This implies the need to have alternative source of animal feed and/or sustainable supplementation. Cereal and legume crop residues and agro-industrial by-products have played a major role in supplying supplemental nutrients to the grazed stock in Eritrea [1]. Studies by [2] evaluated the chemical characteristics and nutritive value of the cereal and legume residues respectively and found out that they contained nutrients that can supply up to $10 \%$ of the total nutrients required by grazing livestock. Furthermore, chemical composition and nutritive value data available for most of crop residues and agro-industrial by-products available in the tropics indicate that they can satisfy significant proportion of the nutritional requirement of ruminant animals [2][8].

Despite their potential use in supplementing ruminant nutrition, crop residues have been shown to have high fibre content besides being low in metabolized energy (ME) and crude protein [9] [10] [11] that result in low degradability in the rumen. Various approaches that have potential to increase digestibility and intake have been proposed. Besides the crop residues, Eritrea's agro-industries produce substantial amounts of byproducts [2] with potential to be used in supplementing the grazing animals thus further availing the much needed nutrients to increase livestock production. However, the chemical composition and nutritive value data for the by-products are scanty. This implies that there is a need to determine the chemical and nutritional characteristics of the by-products so as to optimally integrate them in the animal feeding strategies utilised in Eritrea. The aim of this study was to determine the chemical composition and nutritive value of agro-industrial by-products in ruminant nutrition in Eritrea.

\section{Material and Methods}

\subsection{Sample Collection and Chemical Analysis}

A total of 8 different samples including wheat bran (WB), short (WS) and middling (WM); brewers' dry grain (BDG), hops (BDH) and yeast (BDY); and sesame cakes (SCM and SCT) were collected from milling, beer and oil industries respectively. Dry samples were collected from milling and oil industries while those from the beer industries were wet. The wet samples were sun dried before grinding. Samples for each feedstuff were pooled and milled for the chemical and in situ (nylon bag technique) analysis.

\subsection{Chemical Analysis}

The dry matter $(\mathrm{DM})$ and organic matter $(\mathrm{OM})$ were determined according to the standard methods [12]. The ash content was determined by ashing samples in a muffle 
furnace at $550^{\circ} \mathrm{C}$ for $6 \mathrm{~h}$ while the nitrogen $(N)$ content was determined using Kjeldahl method [12]. The crude protein $(C P)$ was calculated as:

$$
C P=N * 6.25
$$

The crude fiber $(C F)$ and ether extract $(E E)$ were determined by the methods described in the [12]. The nitrogen free extract $(N F E)$ was determined as:

$$
N F E=[100-(C P+E E+C F+A s h)]
$$

The cell wall components (NDF, ADF and ADL) were determined according to [13].

\subsection{In Situ Degradation Procedures}

The nylon bag procedure described by [14] was used in determining the nutritive value of the crop residues considered in this study. In all, a $5 \mathrm{~g}$ of dried sample of the crop residues were milled through a $3 \mathrm{~mm}$ screen. The sample was then weighed in nylon bags $(16 \times 8 \mathrm{~cm}$, pore size 45 to $60 \mathrm{um}$ ) which were then incubated in the rumen of two cattle fitted with rumen cannula. The research adhered to the guidelines proposed in the Guide for the Care and Use of Agricultural Animals in Agricultural Research and Teaching [15].

The bags were withdrawn at 4, 8, 16, 24, 48, 72 and $96 \mathrm{~h}$ intervals following insertion. They were subsequently rinsed with cold water until it became clear. This was followed by drying of the bags and samples at $60^{\circ} \mathrm{C}$ for $48 \mathrm{~h}$. The soluble fraction $(0 \mathrm{~h})$ value was obtained by soaking two bags of the sample in warm water $\left(38^{\circ} \mathrm{C}\right)$ bath for $1 \mathrm{~h}$ which was then followed by washing in cold water for $15 \mathrm{~min}$ in a washing machine. The samples were then dried for $48 \mathrm{~h}$ at $60^{\circ} \mathrm{C}$. The rumen degradation kinetics of DM and OM was calculated using the exponential equation by [14] as:

$$
P=a+b\left(1-e^{-c t}\right)
$$

where $p$ is the percentage degradability for response variable at time $t$ which is the time relative to incubation (hours), a represents the highly soluble and readily degradable fraction (\%), $b$ the insoluble and slowly degradable fraction (\%), $c$ is the rate constant for degradation $\left(\mathrm{h}^{-1}\right)$ and $e$ is the natural logarithm base (2.7182). The effective degradability $(E D)$ of the DM and $\mathrm{OM}$ of each sample was determined using the equation proposed by [16]:

$$
E D=a+\frac{(b * c)}{(c+k)}
$$

where parameters $a, b$ and $c$ are as previously defined while $k$ is the rate constant of passage $\left(\mathrm{h}^{-1}\right)$ which was assumed to be $0.02,0.05$ and 0.08 per hour [16]. The metabolisable Energy $(M E)$ content was estimated using equation described by [16] as:

$$
M E(\mathrm{MJ} / \mathrm{kg} D M)=2.27563+0.1073 D M D
$$

where $D M D$ is rumen dry matter degradability at $48 \mathrm{~h}$ of incubation.

\subsection{Statistical Analysis}

Data on chemical composition and degradation characteristics were subjected to analysis of variance while the least significant differences (LSD) test was used in all cases to 
compare the samples means. Differences were accepted when $\mathrm{P} \leq 0.05$.

\section{Results}

\subsection{Chemical Composition of Crop Residues}

The chemical composition of the agro-industrial by-products are presented in Table 1 . The DM varied between $88.39 \%$ for WB to $92.39 \%$ for the SCT. The WM recorded the highest OM content at $97.52 \%$ while the lowest recorded was from SCT at $89.07 \%$. The SCT recorded the highest ash content at $10.93 \%$ followed by BDY at $10.16 \%$ with the least being obtained from WM at 2.48\%. The CP was highest in SCT at $40.41 \%$ and lowest in WM at $10.11 \%$ while the SCM and SCT contained the highest ME at 11.17 and 11.18 MJ per kg DM respectively. The EE and ADL contents were generally low in all cases for all the by-products. Generally, the results indicated that there was no clear pattern in terms of nutrients content amongst the by-products.

The CP content of the agro-industrial by-products ranged from $10.11 \%$ to $48.20 \%$. The lowest $(\mathrm{P}<0.05)$ was recorded in $\mathrm{WM}$ while the highest $(\mathrm{P}<0.05)$ was obtained from the BDY. The WS had higher $(\mathrm{P}<0.05) \mathrm{CP}$ amongst all the milling by-products with the BDG recording lower $(\mathrm{P}<0.05) \mathrm{CP}$ when compared to the other brewers' by-products. The CF content for different by-products ranged from $1.14 \%$ in BDY to $22.58 \%$ in BDG. The NDF, ADF, and ADL ranged between 3.30\% in BDY to 74.43 in BDG, $1.55 \%$ in BDY to $21.18 \%$ in $\mathrm{BDG}$ and $0.9 \%$ in $\mathrm{BDY}$ to $5.23 \%$ in $\mathrm{BDH}$ respectively. Generally, the BDY had lower $(\mathrm{P}<0.05) \mathrm{CF}, \mathrm{NDF}$ and ADF content. Conversely, the $B D G$ recorded higher values $(P<0.05)$ for the parameters when compared to all other agro-industrial by-products. The WM resulted in lower $(\mathrm{P}<0.05) \mathrm{CF}, \mathrm{NDF}$ and ADF than the other milling by-products.The metabolizable energy (ME) value of the agroindustrial by-products ranged from 8.72 to $11.18 \mathrm{MJ}$ per $\mathrm{kg} \mathrm{DM}$ with the $\mathrm{BDH}$ recording

Table 1. Chemical composition of agro-industrial by-products.

\begin{tabular}{ccccccccc}
\hline & \multicolumn{7}{c}{ Agro-Industrial By-Products } \\
\hline Nutrients $^{2}$ & WB & WS & WM & BDG & BDH & BDY & SCM & SCT \\
\hline DM & $88.39^{\mathrm{a}}$ & $90.42^{\mathrm{b}}$ & $88.9^{\mathrm{a}}$ & $90.17^{\mathrm{b}}$ & $91.35^{\mathrm{b}}$ & $88.46^{\mathrm{a}}$ & $92.00^{\mathrm{c}}$ & $92.39^{\mathrm{c}}$ \\
Ash & $5.32^{\mathrm{b}}$ & $4.45^{\mathrm{c}}$ & $2.48^{\mathrm{a}}$ & $5.32^{\mathrm{b}}$ & $2.53^{\mathrm{a}}$ & $10.16^{\mathrm{d}}$ & $9.82^{\mathrm{d}}$ & $10.93^{\mathrm{f}}$ \\
OM & $94.68^{\mathrm{c}}$ & $95.55^{\mathrm{a}}$ & $97.52^{\mathrm{b}}$ & $94.68^{\mathrm{c}}$ & $97.47^{\mathrm{b}}$ & $89.84^{\mathrm{e}}$ & $90.18^{\mathrm{e}}$ & $89.07^{\mathrm{d}}$ \\
CP & $11.05^{\mathrm{h}}$ & $12.27^{\mathrm{g}}$ & $10.11^{\mathrm{f}}$ & $19.96^{\mathrm{e}}$ & $21.63^{\mathrm{d}}$ & $48.20^{\mathrm{c}}$ & $37.45^{\mathrm{b}}$ & $40.41^{\mathrm{a}}$ \\
EE & $2.98^{\mathrm{ab}}$ & $4.03^{\mathrm{b}}$ & $2.25^{\mathrm{a}}$ & $5.92^{\mathrm{d}}$ & $2.52^{\mathrm{ab}}$ & $0.47^{\mathrm{e}}$ & $16.84^{\mathrm{c}}$ & $15.43^{\mathrm{c}}$ \\
NFE & $67.96^{\mathrm{d}}$ & $66.46^{\mathrm{d}}$ & $79.2^{\mathrm{f}}$ & $46.22^{\mathrm{e}}$ & $60.12^{\mathrm{c}}$ & $40.02^{\mathrm{b}}$ & $27.86^{\mathrm{a}}$ & $26.17^{\mathrm{a}}$ \\
CF & $12.7^{\mathrm{e}}$ & $12.79^{\mathrm{e}}$ & $5.96^{\mathrm{a}}$ & $22.58^{\mathrm{b}}$ & $13.2^{\mathrm{e}}$ & $1.14^{\mathrm{c}}$ & $8.04^{\mathrm{d}}$ & $7.05^{\mathrm{d}}$ \\
NDF & $61.95^{\mathrm{c}}$ & $46.91^{\mathrm{d}}$ & $20.93^{\mathrm{b}}$ & $74.43^{\mathrm{e}}$ & $22.63^{\mathrm{b}}$ & $3.3^{\mathrm{f}}$ & $18.54^{\mathrm{a}}$ & $18.98^{\mathrm{a}}$ \\
ADF & $19.73^{\mathrm{c}}$ & $13.78^{\mathrm{a}}$ & $5.88^{\mathrm{d}}$ & $21.18^{\mathrm{f}}$ & $13.51^{\mathrm{a}}$ & $1.55^{\mathrm{e}}$ & $9.18^{\mathrm{b}}$ & $9.02^{\mathrm{b}}$ \\
ADL & $3.96^{\mathrm{ac}}$ & $3.66^{\mathrm{ac}}$ & $2.51^{\mathrm{ac}}$ & $4.07^{\mathrm{ac}}$ & $5.23^{\mathrm{a}}$ & $0.9^{\mathrm{c}}$ & $1.5^{\mathrm{c}}$ & $1.29^{\mathrm{c}}$ \\
ME (MJ/kg DM) & $10.32^{\mathrm{b}}$ & $10.52^{\mathrm{b}}$ & $9.89^{\mathrm{a}}$ & $8.85^{\mathrm{c}}$ & $8.72^{\mathrm{c}}$ & $\mathrm{ND}^{\mathrm{a}}$ & $11.17^{\mathrm{d}}$ & $11.18^{\mathrm{d}}$ \\
\hline
\end{tabular}

Means within the same row with different superscript are significantly different $(\mathrm{P}<0.05)$. ${ }^{1}$ See text for the description of the Agro-Industrial By-Products. ${ }^{2}$ See text for the description of the nutrients; the values for the Ash, OM, $\mathrm{CP}, \mathrm{EE}, \mathrm{NFE}, \mathrm{CF}, \mathrm{NDF}, \mathrm{ADL}$ are presented as per cent of the $\mathrm{DM}$ content. $\mathrm{ND}=$ Not Determined. 
the lowest value $(\mathrm{P}<0.05)$ of $8.72 \mathrm{MJ}$ per $\mathrm{kg} \mathrm{DM}$. The sesame cakes $(\mathrm{SCM}$ and SCT) recorded higher values $(\mathrm{P}<0.05)$ of 11.17 and $11.18 \mathrm{MJ}$ per $\mathrm{kg} \mathrm{DM}$ respectively.

The in situ DMD, OMD and crude protein (CP) degradability of agro-industrial byproducts are presented in Table 2. The CPD data is presented for the 72 hours beyond which the entire sample had been degraded in most of the by-products. The sesame cakes (SCM and SCT) had the highest $(\mathrm{P}<0.05)$ DMD at all incubation times while the brewer's yeast by-products had the least (BDG and $\mathrm{BDH})$. The $\mathrm{WM}$ had lower values $(\mathrm{P}$ $<0.05)$ compared to the other milling industry by-products except at $0 \mathrm{~h}$ where WB recorded the lowest value of $32.57 \%$.

Table 2. In situ DM, OM and CP degradability of agro-industrial by-products (\% DMD, OMD and CPD).

\begin{tabular}{|c|c|c|c|c|c|c|c|c|c|}
\hline \multirow[t]{2}{*}{ AIBP $^{1}$} & \multicolumn{8}{|c|}{ Time of Incubation in the Rumen (Hrs.) } & \multirow[t]{2}{*}{ SEM } \\
\hline & 0 & 4 & 8 & 16 & 24 & 48 & 72 & 96 & \\
\hline \multicolumn{10}{|l|}{ DMD } \\
\hline WB & $32.57^{\mathrm{ab}}$ & $48.33^{\mathrm{c}}$ & $53.72^{\mathrm{d}}$ & $61.57^{\mathrm{e}}$ & $66.93^{\mathrm{f}}$ & $74.98^{\mathrm{g}}$ & $77.56^{\mathrm{gi}}$ & $77.67^{\mathrm{gi}}$ & 0.169 \\
\hline WS & $36.63^{\mathrm{a}}$ & $47.72^{\mathrm{c}}$ & $53.23^{\mathrm{d}}$ & $60.62^{\mathrm{e}}$ & $66.16^{\mathrm{f}}$ & $76.84^{\mathrm{g}}$ & $79.03^{\mathrm{gi}}$ & $79.03^{\mathrm{gi}}$ & 0.140 \\
\hline WM & $34.34^{\mathrm{ab}}$ & $42.21^{\mathrm{d}}$ & $46.15^{\mathrm{c}}$ & $50.91^{\mathrm{f}}$ & $57.91^{\mathrm{e}}$ & $70.95^{\mathrm{k}}$ & $73.97^{\mathrm{ik}}$ & $73.98^{\mathrm{ik}}$ & 0.208 \\
\hline BDG & $21.77^{\mathrm{c}}$ & $34.62^{\mathrm{e}}$ & $39.11^{\mathrm{f}}$ & $44.77^{\mathrm{d}}$ & $49.27^{\mathrm{g}}$ & $61.31^{\mathrm{h}}$ & $64.47^{\mathrm{h}}$ & $65.05^{\mathrm{h}}$ & 0.293 \\
\hline $\mathrm{BDH}$ & $29.17^{\mathrm{b}}$ & $32.87^{\mathrm{a}}$ & $37.43^{\mathrm{f}}$ & $43.14^{\mathrm{d}}$ & $47.72^{\mathrm{g}}$ & $60.04^{\mathrm{h}}$ & $61.56^{\mathrm{h}}$ & $61.68^{\mathrm{h}}$ & 0.057 \\
\hline SCM & $63.88^{\mathrm{d}}$ & $65.35^{\mathrm{b}}$ & $67.45^{\mathrm{a}}$ & $71.15^{c}$ & $74.90^{\mathrm{h}}$ & $82.87^{j}$ & $85.30^{\mathrm{j}}$ & $85.34^{j}$ & 0.178 \\
\hline SCT & $62.01^{\mathrm{d}}$ & $64.39^{\mathrm{e}}$ & $67.50^{\mathrm{a}}$ & $71.53^{c}$ & $74.91^{\mathrm{h}}$ & $82.98^{j}$ & $85.36^{j}$ & $85.36^{j}$ & 0.081 \\
\hline SEM & 4.200 & 3.334 & 3.140 & 3.001 & 2.882 & 2.403 & 2.421 & 2.378 & \\
\hline \multicolumn{10}{|l|}{ OMD } \\
\hline WB & $32.59^{\mathrm{a}}$ & $47.10^{\mathrm{e}}$ & $52.40^{\mathrm{b}}$ & $59.75^{\mathrm{d}}$ & $65.19^{c}$ & $73.01^{\mathrm{f}}$ & $76.27^{\mathrm{k}}$ & $76.27^{\mathrm{k}}$ & 0.085 \\
\hline WS & $33.94^{\mathrm{a}}$ & $45.56^{\mathrm{e}}$ & $52.46^{\mathrm{b}}$ & $60.47^{\mathrm{d}}$ & $65.44^{\mathrm{c}}$ & $75.78^{\mathrm{g}}$ & $78.15^{j}$ & $78.15^{j}$ & 0.040 \\
\hline WM & $33.87^{\mathrm{a}}$ & $40.57^{\mathrm{d}}$ & $45.57^{\mathrm{c}}$ & $49.40^{\mathrm{b}}$ & $56.23^{\mathrm{e}}$ & $69.67^{\mathrm{h}}$ & $73.11^{\mathrm{i}}$ & $73.12^{\mathrm{i}}$ & 0.023 \\
\hline BDG & $19.23^{\mathrm{b}}$ & $33.68^{c}$ & $38.00^{\mathrm{d}}$ & $44.22^{\mathrm{a}}$ & $48.78^{\mathrm{f}}$ & $60.38^{\mathrm{e}}$ & $63.38^{\mathrm{h}}$ & $63.98^{\mathrm{h}}$ & 0.091 \\
\hline $\mathrm{BDH}$ & $27.63^{c}$ & $31.43^{\mathrm{b}}$ & $36.18^{\mathrm{a}}$ & $42.06^{\mathrm{e}}$ & $45.84^{\mathrm{d}}$ & $58.87^{\mathrm{i}}$ & $60.72^{\mathrm{g}}$ & $60.89^{\mathrm{g}}$ & 0.036 \\
\hline SCM & $64.03^{\mathrm{d}}$ & $65.71^{\mathrm{a}}$ & $67.88^{\mathrm{e}}$ & $71.53^{c}$ & $75.44^{\mathrm{b}}$ & $83.18^{j}$ & $85.78^{\mathrm{f}}$ & $85.78^{\mathrm{f}}$ & 0.016 \\
\hline SCT & $63.51^{\mathrm{d}}$ & $65.89^{\mathrm{a}}$ & $68.43^{e}$ & $71.34^{\mathrm{c}}$ & $75.10^{\mathrm{b}}$ & $83.37^{j}$ & $85.86^{\mathrm{f}}$ & $85.86^{\mathrm{f}}$ & 0.089 \\
\hline SEM & 4.498 & 3.586 & 3.330 & 3.112 & 3.044 & 2.530 & 2.542 & 2.502 & \\
\hline \multicolumn{10}{|l|}{ CPD } \\
\hline WB & $28.22^{\mathrm{e}}$ & $50.26^{\mathrm{b}}$ & $67.36^{\mathrm{fj}}$ & $74.14^{\mathrm{dgj}}$ & $77.58^{\mathrm{g}}$ & $79.79^{\text {ghi }}$ & $79.96^{\text {gh }}$ & - & 0.348 \\
\hline WS & $35.22^{c}$ & $54.98^{\mathrm{a}}$ & $69.82^{\mathrm{f}}$ & $76.70^{\mathrm{d}}$ & $78.50^{\mathrm{g}}$ & $80.96^{\mathrm{hi}}$ & $81.08^{\text {hi }}$ & - & 0.216 \\
\hline WM & $22.05^{\mathrm{d}}$ & $45.62^{\mathrm{c}}$ & $56.11^{\mathrm{e}}$ & $66.97^{\mathrm{b}}$ & $73.03^{\mathrm{g}}$ & $77.10^{\mathrm{h}}$ & $77.58^{\mathrm{h}}$ & - & 0.179 \\
\hline BDG & $27.19^{\mathrm{e}}$ & $36.64^{\mathrm{d}}$ & $48.39^{c}$ & $67.68^{\mathrm{f}}$ & $77.52^{\mathrm{g}}$ & $83.78^{\mathrm{i}}$ & $84.18^{\mathrm{i}}$ & - & 0.114 \\
\hline $\mathrm{BDH}$ & $30.13^{\mathrm{a}}$ & $45.03^{\mathrm{c}}$ & $56.02^{\mathrm{e}}$ & $69.63^{\mathrm{f}}$ & $77.53^{\mathrm{g}}$ & $83.76^{\mathrm{i}}$ & $84.15^{\mathrm{i}}$ & - & 0.188 \\
\hline SCM & $77.80^{\mathrm{b}}$ & $82.57^{\mathrm{e}}$ & $90.75^{\mathrm{ad}}$ & $91.81^{\mathrm{ac}}$ & $92.78^{\mathrm{cf}}$ & $93.82^{\mathrm{f}}$ & $93.82^{\mathrm{f}}$ & - & 0.142 \\
\hline SCT & $78.40^{\mathrm{b}}$ & $82.34^{\mathrm{e}}$ & $90.52^{\mathrm{ad}}$ & $91.87^{\mathrm{ac}}$ & $92.82^{\mathrm{cf}}$ & $94.28^{\mathrm{f}}$ & $94.61^{\mathrm{f}}$ & - & 0.088 \\
\hline SEM & 6.287 & 4.727 & 4.321 & 2.968 & 2.067 & 1.737 & 1.719 & - & \\
\hline
\end{tabular}

Means within the same row with different superscript are significantly different $(\mathrm{P}<0.05)$ while those within the same column with different superscript are significantly different $(\mathrm{P}<0.05)$. ${ }^{1}$ See text for the description of the crop residues. 
The in situ OMD differed amongst and within the sesame cakes, milling and brewery by-products. However, a pattern similar to the one in the DMD was obtained with the cakes having the highest OMD content followed by the milling by-products with least content being obtained from the brewery by-products.

The CPD pattern differed from that of the DMD and OMD except for the sesame cakes which remained higher $(\mathrm{P}<0.05)$ than the brewery and milling by-products. The highest CPD was obtained from SCT at $94.61 \%$ in the $96^{\text {th }}$ hour of incubation while the lowest was from WM at $22.05 \%$ before start of the incubation in the rumen. Generally, an increase in the incubation time led to increase in the CPD for all by-products.

The DM, OM and CP disappearance from the nylon bags incubated in the rumen increased with increase in time. The rate of increase however reduced with increase in the incubation time. In all cases, there was minimal change in DMD, OMD and CPD between hours 72 and 96 . Although, the level of degradability was different at the various incubation times both between and within the feedstuff, it was revealed that there was no significant difference $(\mathrm{P}<0.05)$ within the feedstuff and between the by-products from milling, or brewers' industry after $48 \mathrm{~h}$.

\subsection{Degradability Characteristics}

The percentage DM, OM and CP rapidly soluble fraction (a), potentially degradable fraction $(b)$, rate of degradation of $b$ fraction $(c)$ and the effective degradability (ED) of different by-products are presented in Table 3. The respective values of the DM, OM and $\mathrm{CP} a, b, c,(a+b)$ and ED parameters varied amongst by-products. The highest values of DM, OM and CP a were obtained from SCT at $61.85 \%$, SCM at $63.86 \%$ and $78.40 \%$ from SCT respectively. The respective $b$ values were $44.73 \%$ in $\mathrm{WB}, 46.65 \%$ in WS and $57.08 \%$ in BDG. The DM $(a+b)$ varied between $62.01 \%$ in BDH and $85.43 \%$ in SCT. Respective values for the OM $(a+b)$ were $61.25 \%$ in $\mathrm{BDH}$ and $85.94 \%$ in SCT while they were between $77.58 \%$ in WM and $94.61 \%$ in SCT for the CP. The rate of the degradation of $b$ fraction varied minimally between the DM whose range was between 0.040 in WM and 0.071 in SCM and SCT as the two by-products resulted in a similar value. The rate in $\mathrm{OM}$ was similar to that in $\mathrm{DM}$. The $\mathrm{CP} c$ values were higher than the corresponding DM and OM $c$ values and ranged between 0.077 for BDG and 0.186 for SCM and SCT which had a common value. In general, the value of $c$ was highest in SCM and SCT in all cases. The SEM was generally high for the percentage DM, OM and $\mathrm{CP}$ degradability characteristics and the effective degradability values of different agro-industrial by-products. This could result from variation in the processing procedure rather than the differences in the by-products.

The values for DMED at $0.02,0.05$ and 0.08 hourly rate of passage ranged between $51.90 \%$ to $80.61 \%, 43.16 \%$ to $76.45 \%$ and $38.18 \%$ to $73.95 \%$ respectively. Similarly, respective rates in the OM were $50.50 \%$ to $80.98 \%, 40.77 \%$ to $76.76 \%$ and $35.65 \%$ to $74.23 \%$ while in the CP the rates ranged between $69.58 \%$ to $93.04 \%, 61.13 \%$ to $91.18 \%$ and $55.23 \%$ to $89.74 \%$ respectively. The sesame cakes (SCT and SCM) had higher ( $<$ 0.05) DM, OM and CP ED than all the by-products at all the passage rates.

The DM, OM and CP ED varied among by-products and passage rates. However, there was no significant difference for the DM ED amongst the milling (WB, WS and 
Table 3. The percentage DM, OM and CP degradability characteristics and the effective degradability values of different agro-industrial by-products.

\begin{tabular}{|c|c|c|c|c|c|c|c|c|}
\hline & \multicolumn{7}{|c|}{ Agro-industrial by-products ${ }^{1}$} & \multirow[t]{2}{*}{ SEM } \\
\hline & WB & WS & WM & BDG & $\mathrm{BDH}$ & SCM & SCT & \\
\hline \multicolumn{9}{|l|}{$\mathrm{DM}$} \\
\hline$a$ & $30.61^{\mathrm{ab}}$ & $34.86^{\mathrm{a}}$ & $31.89^{\mathrm{ab}}$ & $20.97^{c}$ & $28.12^{\mathrm{b}}$ & $63.71^{\mathrm{d}}$ & $61.85^{\mathrm{d}}$ & 4.342 \\
\hline$b$ & $47.64^{\mathrm{c}}$ & $44.73^{\mathrm{cd}}$ & $42.86^{\mathrm{d}}$ & $44.28^{\mathrm{cd}}$ & $33.89^{\mathrm{a}}$ & $21.70^{\mathrm{b}}$ & $23.58^{\mathrm{b}}$ & 2.746 \\
\hline$(a+b)$ & $78.25^{\mathrm{f}}$ & $79.59^{\mathrm{e}}$ & $74.75^{\mathrm{d}}$ & $65.25^{\mathrm{b}}$ & $62.01^{\mathrm{c}}$ & $85.41^{\mathrm{a}}$ & $85.43^{\mathrm{a}}$ & 2.363 \\
\hline$c$ perh & $0.042^{\mathrm{a}}$ & $0.044^{\mathrm{ab}}$ & $0.040^{\mathrm{a}}$ & $0.049^{\mathrm{b}}$ & $0.047^{\mathrm{b}}$ & $0.071^{\mathrm{c}}$ & $0.071^{\mathrm{c}}$ & 0.004 \\
\hline \multicolumn{9}{|l|}{ ED (\%) } \\
\hline 0.02 & $63.13^{b}$ & $65.69^{\mathrm{b}}$ & $60.65^{\mathrm{b}}$ & $52.48^{c}$ & $51.90^{c}$ & $80.61^{a}$ & $80.22^{\mathrm{a}}$ & 3.218 \\
\hline 0.05 & $53.16^{\mathrm{a}}$ & $56.37^{\mathrm{a}}$ & $51.83^{\mathrm{a}}$ & $43.16^{\mathrm{b}}$ & $44.84^{\mathrm{b}}$ & $76.45^{c}$ & $75.70^{c}$ & 3.603 \\
\hline 0.08 & $48.10^{c}$ & $51.58^{\mathrm{c}}$ & $47.44^{\mathrm{c}}$ & $38.18^{\mathrm{a}}$ & $41.12^{\mathrm{a}}$ & $73.95^{\mathrm{b}}$ & $72.98^{b}$ & 3.785 \\
\hline \multicolumn{9}{|l|}{$\mathrm{OM}$} \\
\hline$a$ & $30.41^{\mathrm{a}}$ & $32.07^{\mathrm{a}}$ & $31.51^{\mathrm{a}}$ & $18.26^{\mathrm{b}}$ & $26.50^{c}$ & $63.86^{\mathrm{d}}$ & $63.34^{\mathrm{d}}$ & 4.651 \\
\hline$b$ & $46.51^{\mathrm{b}}$ & $46.65^{\mathrm{b}}$ & $42.36^{c}$ & $45.94^{\mathrm{b}}$ & $34.75^{\mathrm{d}}$ & $21.99^{\mathrm{a}}$ & $22.60^{a}$ & 2.832 \\
\hline$(a+b)$ & $76.92^{\mathrm{a}}$ & $78.72^{\mathrm{b}}$ & $73.87^{c}$ & $64.20^{\mathrm{d}}$ & $61.25^{\mathrm{e}}$ & $85.85^{\mathrm{f}}$ & $85.94^{\mathrm{f}}$ & 2.484 \\
\hline$c$ per h & $0.041^{\mathrm{c}}$ & $0.043^{\mathrm{cd}}$ & $0.040^{c}$ & $0.046^{\mathrm{b}}$ & $0.045^{\mathrm{bd}}$ & $0.071^{\mathrm{a}}$ & $0.071^{\mathrm{a}}$ & 0.004 \\
\hline \multicolumn{9}{|l|}{ ED (\%) } \\
\hline 0.02 & $61.90^{c}$ & $64.03^{\mathrm{d}}$ & $59.97^{\mathrm{e}}$ & $50.50^{\mathrm{a}}$ & $50.71^{\mathrm{a}}$ & $80.98^{\mathrm{b}}$ & $80.93^{\mathrm{b}}$ & 3.238 \\
\hline 0.05 & $52.21^{\mathrm{c}}$ & $54.28^{\mathrm{a}}$ & $51.24^{\mathrm{b}}$ & $40.77^{\mathrm{d}}$ & $43.45^{\mathrm{e}}$ & $76.76^{\mathrm{f}}$ & $76.60^{\mathrm{f}}$ & 3.755 \\
\hline 0.08 & $47.34^{\mathrm{b}}$ & $49.30^{c}$ & $46.89^{b}$ & $35.65^{\mathrm{a}}$ & $39.67^{\mathrm{d}}$ & $74.23^{\mathrm{e}}$ & $73.99^{e}$ & 3.993 \\
\hline \multicolumn{9}{|l|}{$\mathrm{CP}$} \\
\hline$a$ & $28.22^{\mathrm{a}}$ & $35.22^{\mathrm{b}}$ & $22.05^{c}$ & $27.12^{\mathrm{a}}$ & $30.09^{\mathrm{d}}$ & $77.80^{\mathrm{e}}$ & $78.40^{\mathrm{e}}$ & 6.289 \\
\hline$b$ & $51.74^{\mathrm{b}}$ & $45.85^{\mathrm{a}}$ & $55.53^{c}$ & $57.08^{\mathrm{d}}$ & $54.07^{\mathrm{e}}$ & $16.03^{\mathrm{f}}$ & $16.22^{\mathrm{f}}$ & 4.693 \\
\hline$(a+b)$ & 79.96 & 81.08 & 77.58 & 84.20 & 84.16 & 93.82 & 94.61 & 1.714 \\
\hline$c$ per h & $0.175^{\mathrm{a}}$ & $0.176^{\mathrm{a}}$ & $0.119^{\mathrm{b}}$ & $0.077^{\mathrm{c}}$ & $0.082^{c}$ & $0.186^{\mathrm{d}}$ & $0.186^{\mathrm{d}}$ & 0.013 \\
\hline \multicolumn{9}{|l|}{ ED (\%) } \\
\hline 0.02 & $74.65^{\mathrm{a}}$ & $76.39^{\mathrm{b}}$ & $69.58^{c}$ & $72.49^{\mathrm{d}}$ & $73.51^{\mathrm{e}}$ & $92.27^{\mathrm{f}}$ & $93.04^{\mathrm{g}}$ & 2.481 \\
\hline 0.05 & $68.46^{\mathrm{g}}$ & $70.91^{\mathrm{f}}$ & $61.13^{\mathrm{e}}$ & $61.82^{\mathrm{d}}$ & $63.62^{c}$ & $90.43^{\mathrm{b}}$ & $91.18^{\mathrm{a}}$ & 3.334 \\
\hline 0.08 & $63.72^{\mathrm{a}}$ & $66.72^{\mathrm{b}}$ & $55.23^{c}$ & $55.23^{\mathrm{c}}$ & $57.40^{\mathrm{d}}$ & $89.01^{\mathrm{e}}$ & $89.74^{\mathrm{f}}$ & 3.884 \\
\hline
\end{tabular}

Means within the same row with different superscript are significantly different $(\mathrm{P}<0.05)$. ${ }^{1}$ See text for the description of the agro-industrial by-products. ${ }^{2}$ Not significant.

$\mathrm{WM}$ ), the brewery (BDG and $\mathrm{BDH}$ ) and sesame cakes (SCM and SCT) by-products. The OM ED for the WS within the milling by-products was always higher $(\mathrm{P}<0.05)$ as did the $\mathrm{BDH}$ and SCM between the brewery and sesame cake by-products respectively.

\section{Discussion}

This study has provided vital information on the chemical composition as well as the nutritive value of different agro-industrial by-products produced in Eritrea. As expected, the composition and nutritional values varied within (by-products from a common crop) and between by-products. This implies that they would supply different quantity and 
quality nutrients when used in livestock feeding [17], while studying the chemical composition, DM and in vitro gas production of different ruminant feedstuff noted that the difference in chemical composition as well as the feeding quality between alternative feedstuffs could be explained by the variation in the composition of the original material, the method used in processing (physical or chemical) and type of components extracted.

The values for different parameters used in evaluating the ruminant feedstuffs obtained in this study were compared to findings from other studies with care being taken to consider those obtained from study areas and production systems similar to the conditions found in Eritrea to avoid bias. It was found that the CP and EE for WB reported by [18] were higher than those obtained in the present study while the NDF and ADF were lower. Similarly, [19] reported higher values for the CP, EE and NDF in WM than those obtained from this study. However, the CP for BDG in the present study was similar to that reported by [20] as did the CP content in SCM which matched that reported by [21] and [22].

The DMD, which is an indicator of the level of cell walls in a feedstuff, varied within and between by-products. This implies that the values of DM, OM and CP $a, b$ and $(a+$ $b$ ) would be dependent on the content and the composition of the cell walls of particular feedstuff. [23] reported that there are strong correlations among the $b$ fraction and the NDF, ADF and ADL contents of test feedstuff. The study further demonstrated that the content and the composition of the cell walls are the best variables to describe the variation of DM $(a+b)$ of the feedstuff. It is [24] who determined the relationship between the degradability parameters $a, b$ and $c$ and the chemical composition of 60 test feeds and noted that the slowly fermentable structural carbohydrates in feedstuff are the determinant of the degradation characteristics in the rumen. Generally, SCM and SCT had high levels of DMD, OMD and CPD at all incubation times. This can be attributed to the availability of rumen degradability nitrogen thus optimizing on the microbial activity which would then enhance the sesame cake by-products to be degraded to their potential. Despite high NDF in WB, its corresponding DMD and CPD were higher than in the WM which can be explained by high levels of soluble containing fraction of DM and $\mathrm{CP}$ as well as the high hemicellulose in NDF content that tend to have high degradability.

The values for the degradability parameters $a, b$ and $c$ obtained from this study match most of those reported in other studies. For instance, the values of the DM $a$ and $c$ fractions for WB were similar to those obtained by [20] while the DM $c$ fraction in BDG reported by [19] is similar to that of the present study. [22] also presented CP $c$ fraction similar to the one obtained in this study. This is possible since the industrial processing would be expected to follow the same principles and probably use similar machinery in the extraction resulting in by-products that only differ as a result of other factors rather than the extraction procedures. Besides, it is common to find commonality in different crop production conditions from different countries implying that the differences might not be such huge. It is however possible to find small differences in similar by-products in different studies such as the one by [20] who reported a slightly higher DM $c$ fraction in BDG this would be explained by the use of test feed that was 
low in NDF. Similarly, [21] reported slightly lower DM $a c$ and higher $b$ fractions in SCT and SCM than those obtained in the current study. The small differences were expected and could be explained by factors such as variation in laboratory equipment and techniques as well as differences in the milling screen sizes among others.

\section{Conclusion}

This study has shown that different agro-industrial by-products differ in terms of chemical composition as well as in nutritional value. Generally, the wide variation in chemical composition, $\mathrm{DMD}, \mathrm{OMD}, \mathrm{CPD}$, and $\mathrm{ME}$ offer farmers huge flexibility in formulating rations according to the productive performance of target animals. By determining the chemical composition and the nutritional value of different by-products, the findings have demonstrated the opportunity available in utilizing them in ruminants feeding. It is evident that legume by-products are superior in terms of nutritional value when compared to the cereal based ones. However, it is important to evaluate the availability of the nutrients to the target animal by carrying out feeding trials and determining the performance (such as growth rate) of animals fed on diet incorporating different byproducts.

\section{Acknowledgements}

The authors would like to recognize Japan International Corporation Agency (JICA) for provision of financial support for this study and Hamelmalo Agricultural College (HAC) of Eritrea for granting the first author permission to participate in the research.

\section{References}

[1] FAO (2006) Food and Agricultural Organization of the United Nation. Suttie, J.M. and Reynolds, S.G., Eds.

[2] Haile, E., Njonge, F.K., Goitom, A. and Gicheha, M.G. (2016) Production and Potential Utilization of Crop Residues and Agro-Industrial By-Products in Ruminant Nutrition in Eritrea. RUFORUM Biennial Conference: Linking Universities with Private Sector, Governments and Other Stakeholders in Support of Agricultural Development in Africa, Cape Town, 17-21 October 2016 (in Press).

[3] Chimwano, A.M. (1990) Zambia's Farm Livestock Feedstuffs: Their Nutrient Content and Nutritive Value. University of Zambia, Lusaka, Zambia, 12 p.

[4] Aregheore, E.M. (2000) Crop Residues and Agro-Industrial By-Products in Four Pacific Island Countries: Availability, Utilization and Potential Value in Ruminant Nutrition. Asian-Australian Journal of Animal Sciences, 13, 266-269.

[5] Abrar, A.S., Khan, M.A., Mahr-Un-Nisa and Sarwar, M. (2004) Agro-Industrial By-Products as a Potential Source of Livestock Feed: A Review. International Journal of Agriculture and Biology, 2, 307-310.

[6] Afshar, M.A. and Nader, M.S. (2008) Nutritive Value of Some Agro-Industrial By-Products for Ruminants: A Review. World Journal of Zoology, 3, 40-46.

[7] Naser, M.S., Bayaz, A.Z., Ramin, S., Alireza, A., Abolfaze, A.G. and Mehdi, M. (2011) Determining Nutritive Value of Soybean Straw for Ruminant Using Nylon Bag Technique. Pakistan Journal of Nutrition, 10, 838-841.

[8] Mugerwa, S., Kabirizi, J., Zziwa, E. and Lukwago, G. (2012) Utilization of Crop Residues and Agro-Industrial By-Products in Livestock Feed and Feeding Systems in Uganda. Inter- 
national Journal of Biosciences, 2, 82-89.

[9] Devendra, C. (1991) Technologies Currently Used for the Improvement of Straw Utilization in Ruminant Feeding Systems in Asia. In: Romey, D.K., Ørskov, E.R. and Gill, M., Eds., Proceedings of the NRI/MARDI Workshop on the Utilization of Straw in Ruminant Production Systems, 7-11 October 1991, Natural Resources Institute and Malaysian Agricultural Research and Development Institute, Kuala Lumpur, 1-19.

[10] Preston, T.R. (1995) Tropical Animal Feeding. A Manual for Research Workers. FAO Animal Production and Health, Rome, Paper No. 126, 305.

[11] Tingshuang, G., Sánchez, M.D. and Yu, G.P. (2002) Composition, Nutritive Value and Upgrading of Crop Residues. Animal Production Based on Crop Residues-Chinese Experiences. FAO Animal Production and Health Paper 149.

[12] AOAC International (2005) Official Methods of Analysis of AOAC International. AOAC International, Rockville.

[13] Van Soest, P.J., Robertson, J.D. and Lewis, B.A. (1991) Methods for Dietary Fibre, Neutral Detergent Fibre and Non-Starch Polysaccharides in Relation to Animal's Nutrition. Journal of Dairy Science, 74, 3583-3597. https://doi.org/10.3168/jds.S0022-0302(91)78551-2

[14] Ørskov, E.R., Hovell, F.D.D. and Mould, F. (1980) The Use of the Nylon Bag Technique for the Evaluation of Feedstuffs. Tropical Animal Production, 5, 195-213.

[15] Federation of Animal Science Societies (1999) Guide for the Care and Use of Agricultural Animals in Agricultural Research and Teaching. Committees to Revise the Guide for the Care and Use of Agricultural Animals in Agricultural Research and Teaching, Savoy.

[16] Bhargava, P.K. and Ørskov, E.R. (1987) Manual for the Use of Nylon Bag Technique in the Evaluation of Feedstuffs. Rowett Research Institute, Aberdeen.

[17] Getachew, G., Robinson, P.H., de Peter, E.J. and Taylor, S.J. (2004) Relationship between Chemical Composition, Dry Matter Degradability and in Vitro Gas Production of Several Ruminants Feed. Animal Feed Science Technology, 111, 57-71. https://doi.org/10.1016/S0377-8401(03)00217-7

[18] Paya, H., Tagfizadeh, A., Janamohanadi, H. and Moghadam, G.M. (2008) Ruminal Dry Matter and Crude Protein Degradability of Some Tropical (Iranian) Feed Used in Ruminant Diet Estimated Using in Situ and in Vitro Techniques. Research Journal of Biological Sciences, 3, 720-725.

[19] Batajoo, K.K. and Shaver, D.R. (1998) In Situ Dry Matter, Crude Protein, and Starch Degradability of Selected Grains and By-Product Feeds. Animal Feed Science Technology, 71, 165-176. https://doi.org/10.1016/S0377-8401(97)00132-6

[20] Paya, H., Taghizadeh, A., Lashkari, S. and Shirmohammadi, S. (2012) Evaluation of Rumen Fermentation Kinetics of Some By-Products Using in Situ and in Vitro Gas Production Technique. Slovak Journal of Animal Sciences, 45, 127-133.

[21] Mahala, A.G. and Gomaa, A.S. (2007) Effect of Heat Treatment on Sesame Cake Protein Degradation. Research Journal of Animal and Veterinary Sciences, 2, 39-42.

[22] Marghazani, I.B., Jabbar, M.A., Pasha, T.N. and Abdullah, M. (2013) Ruminal Degradability Characteristics in Vegetable Protein Sources of Pakistan. The Journal of Animal and Plant Sciences, 23, 1578-1582.

[23] Bruno-Soaresa, A.M., Abreua, J.M., Guedesb, C.V. and Dias-da-Silvab, A.A. (2000) Chemical Composition, DM and NDF Degradation Kinetics in Rumen of Seven Legume Straws. Animal Feed Science and Technology, 83, 75-80. https://doi.org/10.1016/S0377-8401(99)00113-3

[24] Woods, V.B, O’Mara, F.P. and Moloney, A.P. (2003) The Nutritive Value of Concentrate 
Feedstuff for Ruminant Animals. Part I: In Situ Ruminal Degradability of Dry Matter and Organic Matter. Animal Feed Science Technology, 110, 111-130.

https://doi.org/10.1016/S0377-8401(03)00220-7

Submit or recommend next manuscript to SCIRP and we will provide best service for you:

Accepting pre-submission inquiries through Email, Facebook, LinkedIn, Twitter, etc. A wide selection of journals (inclusive of 9 subjects, more than 200 journals) Providing 24-hour high-quality service User-friendly online submission system Fair and swift peer-review system Efficient typesetting and proofreading procedure Display of the result of downloads and visits, as well as the number of cited articles Maximum dissemination of your research work

Submit your manuscript at: http://papersubmission.scirp.org/

Or contact ojas@scirp.org 